\title{
WAR AND THE WELFARE STATE: THE CASE OF ITALY, FROM WWI TO FASCISM
}

\author{
GUERRA Y WELFARE STATE: EL CASO DE ITALIA, \\ DE LA 1. ${ }^{a}$ GUERRA MUNDIAL AL FASCISMO
}

Ilaria Pavan*

Scuola Normale Superiore di Pisa (Italia)

\begin{abstract}
On the eve of WWI Italy was among the less advanced European countries in terms of social policies. This was due both to the the frailty of the state building process, began in 1860 , and to the relative weakness of the workers' organizations. In accordance with recent literature that shows the manifold causal links between the developments of the welfare state and war, this article aims at examining the peculiarities of the Italian scenario. Faced with the new social needs triggered by the total war, Italian governments experienced an unprecedented activism in the field of social policies, especially in the last year of the conflict and in the immediate post-war period. This was a radical evolution with respect of the pre-war context. By analyzing the various measures adopted, and the rethoric that justified and surrounded them, this paper shows how WWI can be considered as the real starting point in the history of the Italian welfare state.
\end{abstract}

KEYWORDS: Italy, WWI, social insurances, soldiers, reforms

RESUMEN: Antes del inicio de la Primera Guerra Mundial, Italia se encontraba entre los países europeos menos avanzados en términos de políticas sociales. Esto se debió tanto a la fragilidad del proceso de construcción del Estado, que comenzó en 1860, como a la debilidad relativa de las organizaciones de trabajadores. Atendiendo a líneas de acercamiento recientes que muestra los múltiples vínculos causales entre los desarrollos del Estado de Bienestar y la guerra, este artículo pretende examinar las peculiaridades del escenario italiano. Enfrentados a las nuevas necesidades sociales provocadas por la guerra total, los gobiernos italianos experimentaron una actividad sin precedentes en el campo de las políticas sociales, especialmente en el último año del conflicto y en el período inmediato de posguerra, lo que supuso una evolución radical con respecto al contexto de preguerra. Al analizar las diversas medidas adoptadas, y la retórica que las justificaba y rodeaba, este texto muestra cómo la Primera Guerra Mundial puede considerarse como el verdadero punto de arranque en la construcción del Welfare State italiano.

PALABRAS CLAVE: Italia, 1. ${ }^{a}$ Guerra Mundial, Seguros Sociales, soldados, reformas.

* Correspondence to: Ilaria Pavan. Scuola Normale Superiore di Pisa. Piazza dei Cavalieri 7, 56126 Pisa (Italia) - ilaria. pavan@sns.it - http://orcid.org/0000-0002-7960-4215

How to cite: Pavan, Ilaria (2019). "War and the Welfare State: The Case of Italy, from WWI to Fascism»; Historia Contemporánea, 61, 835-872. (https://doi.org/10.1387/hc.20281).

Received: 9 October, 2018; Accepted: 11 January, 2019.

ISSN 1130-2402 - eISSN 2340-0277 / (C) 2019 UPV/EHU 
Wars have long constituted a gray zone in the history of the welfare state; the question of the origins and development of social protection systems has primarily been viewed in relation to processes of modernization, or as an instrument for managing social conflict. As some have noted, in mainstream comparative welfare-state literature "war is typically considered a rare, anomalous contingency conceptualized as an exogenous shock, an 'abnormal event,' a 'black swan' emergency or a critical juncture." ${ }^{1}$ War has therefore tended to fall outside the scope of research preferred by historians and social scientists, who are interested in tracing general laws and models of welfare-state development and more inclined to hypothesize a "sharp trade-off between guns and butter and a negative impact of military conflict on social protection." 2

A recent literature has instead highlighted the existence of a clear causal link between wars - particularly the total wars of the twentieth century - and the development of modern social protection systems in many contexts both inside and outside of Europe, ${ }^{3}$ emphasizing how the two world wars were "a crucial catalyst for the creation of the modern welfare state." 4 The welfare-warfare link has also been examined in relation to processes promoting social equality and forms of distributive equity, not only through the introduction of a more ramified social legislation, but through reforms in the structure of national fiscal systems that were undertaken due to wartime contingencies. ${ }^{5}$

In recent years, Italian historiography has also begun to approach the analysis of welfare-state development from the angle of war. ${ }^{6}$ With a focus almost exclusively on World War I, some individual fields have begun to be explored, particularly with regard to the condition of veterans

${ }^{1}$ Obinger, Petersen, 2017, p. 203

2 Obinger, Petersen, 2017, p. 204. One exception is the case of the United Kingdom, given that studies immediately connected the development of the Beveridge Plan, and the subsequent social measures introduced by the Labor governments, to the contingencies of World War II.

${ }^{3}$ See especially Obinger, Petersen, Starke, 2018; Moses, 2018, pp. 212-270; Obinger, Petersen, 2017; Scheidel, 2017; Castle, 2010; Gal, 2007; Revue d'histoire de la protection sociale, 9, 2016, n. 1, special issue "Grande Guerre e protection social"; Klausen, 1998.

4 Scheidel 2017, p. 53.

5 Steve, Stasavage, 2017.

6 There are several studies of the overall evolution of the Italian welfare state (see especially Cherubini 1977; Silei 2003). But although they cover the period of World War I, they have not focused on the connections between this conflict and developments in welfare. 
and the disabled. ${ }^{7}$ But no assessment of the results achieved in Italy by government welfare policies between the war and the period immediately after it has yet been presented, nor have certain unique aspects of the Italian scene been looked at in comparison with other national contexts. ${ }^{8}$

It is common knowledge that Italy entered the war with only a patchy, hazy social protection system: it was geared (in a very biased way) only toward industrial workers, had many obvious gaps, especially in the field of healthcare and assistance, and there was a clear lack of state commitment to funding welfare measures. On the eve of the war, only $4.8 \%$ of the population was covered by some form of social protection (compared to $42.8 \%$ in Germany and $36.3 \%$ in Great Britain) ${ }^{9}$ and only a paltry $1.56 \%$ of overall government spending was allocated to welfare in $1914 .^{10}$ The country was thus clearly lagging behind the rest of Europe. If this was the starting point in Italy, how incisive and lasting were the new policies regarding social insurance and assistance that were set in motion by the conflict? What political outlooks and what kinds of expertise did they reflect? How did the last few fragile Liberal administrations handle the complex phase of postwar transition? What situation was bequeathed to the new Fascist government?

Moving through the vast labyrinth of laws passed during the war (some 337 measures tied in some way to the social sphere had been issued in Italy by October 1919) ${ }^{11}$ can be disorienting. The provisions range from old-age pensions to accident insurance, from life insurance policies for soldiers to relief payments for families, from job placement for the disabled to unemployment benefits, from aid to widows and orphans all the way to social housing projects. This web of initiatives must be examined as a whole, because they were complementary. Since they were often introduced by decree, and thus lacked the useful framework of parliamentary discussion and debate, any attempt at a detailed reconstruction

7 Bracco, 2012; Procacci, 2013; Pironti, 2015; Salvante 2105; Rapini, 2016; Quagliaroli, 2016; Pavan Della Torre, 2016; Labanca, 2016; Ferrera-Vergallo, 2018; Quagliaroli, 2018; Masina 2018.

${ }^{8}$ In comparative studies (Köhler-Zacher, 1982; Wall-Winter, 1988; Winter-Robert 1997-2007; Bonzon 2003 Italy has not been among the cases analyzed. The only exception is Obinger, Petersen, Starke, 2018.

9 Alber, 1983, p. 220.

10 Luzzati, Portesi 1984, p. 123.

11 For a chronological list of measures, see Ministero per l'Assistenza Militare e le Pensioni di guerra, 1919, pp. 91-116. 
of their authorship, aims, and evolution runs up against undeniable obstacles. The incomplete, scattered nature of the sources, which stems in part from the fact that in Italy, the management of social assistance and insurance was divided up among many different institutions (and that the country had no Ministry of Labor and Welfare until June 1920), does not make it easy for scholars to approach a subject like the history of welfare, which necessarily involves juggling multiple perspectives and areas of expertise.

Without pretending to be systematic, this article will offer an overview of the main welfare measures introduced by Italian governments during World War I and during the difficult months of demobilization after the war, and thus will look at the initiatives backed by political and institutional forces. It will highlight the undeniable scope of the attempted reform, and how it marked a clear break with the timid social policies of previous decades. This break was visible in its guiding principles and in its institutions, but also in the vocabulary employed, and references to new rights of citizenship crop up in the words of leading figures of that era. It will also point out the contradictions and weaknesses of the initiative, which became more pronounced under the last few Liberal administrations. At the end of 1922, these deficiencies, which can be seen above all in measures that were planned but never carried out (such as those regarding health insurance or tax reform), left the new Fascist government with a social protection system that had certainly been redesigned in comparison to the pre-war system, and in some ways mirrored coeval programs around Europe, but which in other spheres - health insurance, in particular-still reflected incomplete, inadequate visions and institutions.

\section{1. "A war of ideas": assistance and insurance for a nation at arms}

In October 1919, in their introduction to a volume titled L'assistenza di guerra in Italia ${ }^{12}$ (Wartime Assistance in Italy), two anonymous bureaucrats at the Ministry of Military Assistance and War Pensions called the work of this recently founded ministry-established by a decree of the Boselli administration on November 1, 1917, and entrusted to the direction of the Reformist Socialist Leonida Bissolati-one of the most signifi-

12 Ministero per l'Assistenza Militare, 1919. 
cant institutional innovations to have emerged from the war. Even the two bureaucrats overseeing the publication of this commemorative volume could see that it marked a clear intensification of the government's role in the field of welfare.

This war has also been a war of ideas; out of its miseries and disasters, a shining path has been charted for the goals of the state [...] It has laid the foundations for us to build a noble edifice of human fellowship. ${ }^{13}$

Founded, not coincidentally, just a few days after the Italian army's defeat at Caporetto-hence with the clear purpose of helping to control an ever more volatile home front - the new ministry nevertheless constituted a clear leap in the forms and scope of assistance that the state decided to provide to its citizens. Underscoring how the war had caught Italy "without the desirable Ministry of Social Assistance and Insurance that had already been created in almost all other nations," 14 the officials hoped that the new institution would be the first step towards a Ministry of Government Assistance, period. Upon leaving the helm of the ministry in December 1918, Minister Bissolati wrote:

Your work is far from over. There are still far too many who are entitled to assistance for reasons connected to the war, and are still awaiting individual acknowledgment of these rights; in addition, there are all those whom recent events have called on to make new and greater concessions. This in itself is a considerable task: but there is more to be done. So I express the strong hope, and consider it wellgrounded, that the temporary function of military assistance will offer firm foundations for erecting a Ministry of Government Assistance, which would bring together the existing institutions that oversee pensions and insurance. This would constitute the loftiest kind of social initiative for a democracy and, since it would merge and coordinate pre-existing institutions, would be a reform that streamlines the task of administration..$^{15}$

13 Ibid., 1919, p. VI and VII. This volume was presented at the Third Inter-Allied Conference for the Protection of Disabled Veterans, held in Rome in October 1919.

14 Ibid., 1919, p. 15

15 Ibid., 1919, p. 31. 
Until a Ministry of Government Assistance could be founded, the Ministry of Military Assistance would see to "coordinating the various services handled by some seven state agencies and guiding them in a single direction"16: words that hint at the problem-a long-term issue in the history of the Italian welfare state-of the overlapping roles parceled out among many different institutions, which were often territorial about their expertise, autonomy in decision-making, and funding.

The ministry's task was to pay out pensions to veterans, offer support to the families of those serving, wounded, or killed, provide assistance to the injured and disabled, in other words, oversee "all forms of assistance benefitting all those affected by the war." 17 This emphasis on the word "all" implicitly acknowledges that the total mobilization generated by the conflict meant that the ministry's function went beyond support for soldiers. For instance, transferable war pensions also ended up going to their wives, widows, children, and parents, and within the still hazy landscape of Italian assistance and insurance, they took on a quality that - to stretch the term a bit-could perhaps be called proto-universalist.

Another extremely significant aspect was the introduction of an expanded definition of "family," as regarded the beneficiaries of the new insurance and assistance programs. In a major break with the framework of family law laid out by the Liberal civil code of 1865 , Decree no. 1726 of October 27, 1918 (which overhauled the entire war pension system) made decisive changes to indirect benefits. ${ }^{18}$ Embracing a distinctly modern, secular conception of family ties in which, for the first time, no distinctions were made between the rights of married and unmarried couples, the decree expanded the scope of aid granted to former combatants and their relatives. As the aforecited volume published by the Ministry of Military Assistance explained, "Putting aside old legal traditions and prejudices, family relationships are considered with a modern breadth of outlook and, one might say, almost purely by the yardstick of natural law." 19 Pension laws now incorporated the concept of a person "equivalent to a widow," giving a cohabiting partner or a fiancée the same rights as a spouse, and

${ }^{16}$ Ministero per l'Assistenza Militare, 1919, p. 28. Bissolati's resignation was motivated by serious conflicts with Foreign Minister Sidney Sonnino.

17 Ibid, 1919, p. 26. The emphasis is in the original.

18 The regulations regarding the transferability of pensions to "needy parents" led, for example, to the payment of 47,000 new benefit checks in the five years that followed.

19 Ministero per l'Assistenza Militare, 1919, p. 27. 
making it possible for a pension to be transferred to such survivors based only on a verbal declaration by the soldier in the presence of two witnesses. Likewise, natural children whose paternity had been recognized were given equal status to legitimate offspring. A few weeks after its introduction, the measure was described by the undersecretary of the Ministry of Military Assistance, the Liberal Democrat Mario Cermenati:

Having granted due consideration to public attitudes in this stage of our civilization, and lovingly examined the living conditions of our people, lawmakers have come to believe that the sphere of emotional and economic relationships revolving around the domestic hearth is not limited to the one described by the Civil Code; that in addition to the legitimate family, there are de facto families based on sexual union and the resulting ties of kinship [...]. The tears shed by these unofficial families are no less anguished and heartfelt then those of a family by law. ${ }^{20}$

The decree establishing equal rights for de facto families was preceded, in April 1918, by an analogous provision regarding per-diem benefit payments for combatants and their families. Sponsored once again by the Ministry of Military Assistance, which had taken on the role of welfare management, the provision was introduced through a tool much less official than a decree, an ordinary ministerial circular:

"ILLEGITIMATE FAMILIES: [...] There are members of the military currently in service who, although they have not, for various reasons, entered into a legal bond of matrimony with the woman they love, have created a true de facto family union with her, often strengthened by the birth of children [...] In the case of such unions, the Ministry has determined that per-diem support is to be granted. ${ }^{21}$.

While the measures on behalf of military families granted women "only a mediated form of social citizenship through the head-of-house-

${ }^{20}$ Cermenati, 1918, p. 289.

21 Circular no. 40 of the Ministry of Military Assistance, April 22, 1918. The granting of benefits to families was overseen by municipal and provincial commissions set up for the purpose, but at present little is known about how they operated. See Crocella, Mazzonis, 2002, p. 894. According to a volume published in 1930 in the Carnegie Endowment for International Peace's Italian series, not more than $63 \%$ of those entitled to them received cash benefits; see Serpieri 1930, p. 225. 
hold, fostering a gendered system of social insurance in future welfare states," 22 in Italy this inclusion of de-facto families nevertheless marked a clear break in with the Catholic, bourgeois conception of the family, and a significant rent in the sturdy fence that civil law had erected around it. And it is no coincidence that the Fascist government, as early as 1923, hastened to do away with this specific reform in the war pension law.

The broader new forms of support to men in the trenches and their families that the Orlando administration introduced, especially through the Treasury Ministry and the Ministry of Military Assistance, were not meant to encourage dependency, however. With a tone and emphasis that reveals elements of the productivity-focused, technocratic outlook that characterized Francesco Saverio Nitti, who was Treasury Minister at the time, it was emphasized that "aid, while aiming to lift the needy out of poverty, must primarily be geared to providing them with the means to work and become independent: every act of social insurance must, if possible, also be an act of production." 23 And one can see a similar attitude in other important benefits introduced for soldiers, officers, and their families, which not coincidentally, came about through the efforts of Treasury Minister Nitti. These were free life insurance policies for combatants, also introduced shortly after Caporetto, in December 1917, ${ }^{24}$ and abundantly advertised through trench newspapers. Initially envisioned only for enlisted men, they were extended a few months later to officers, ${ }^{25}$ as well as to natural and legitimate children and to parents. ${ }^{26}$ The policies, issued by the Istituto Nazionale delle Assicurazioni (INA - National Insurance Institute), could be taken out free of charge since the cost was entirely covered by the state, making them unlike any other measure in Europe at the time. By May 1918, 480,000 policies had been issued, and an internal memo from the directors of the INA suggests that the initiative was enthusiastically received:

22 Thébaud, 2003, p. 79.

${ }^{23}$ Ministero per l'Assistenza Militare, 1919,p. 92. The italics are in the original.

24 Introduced with Decree no. 1970 of December 10, 1917. These policies guaranteed a fixed amount to be paid upon the death of the insured soldier or at their thirty-year maturity.

${ }_{25}$ Decree no. 374 of March 7, 1918.

26 Decree no. 1953 of December 8, 1918. 
It is very interesting to read the letters that are coming in from families and from soldiers themselves at the front. The social goals pursued by the government with the introduction of these policies have been clearly grasped both by the army and by the civilian population. ${ }^{27}$

In Nitti's view, but also in the eyes of Alberto Beneduce and Bonaldo Stringher, who were respectively CEO and president of the INA at the time, the policies were not meant to merely be a tool of aid or support, but an "act of production," since the decree envisioned that they could be cashed in even three months after discharge, "on the condition that their value be reinvested in tools of labor and productivity." Due to the delayed growth of private insurance in Italy compared to other European countries, this life insurance initiative was part of an attempt, already undertaken before the war by the INA leadership, to spread the idea of insurance and personal savings to ever broader sectors of the public.

As in the case of war pensions, this tool designed to provide soldiers and their families with an insurance-based form of support not only broke with the classic, rigid Liberal framework of family law, but with the idea of family in itself, since it, too, allowed partners, illegitimate children, or even "old friends" to be named as beneficiaries in the event of the bearer's death. Terms such as "heart" and "sentiments" - definitely not ordinary language for bureaucrats - cropped up in official statements. Nitti wrote:

Every soldier in the trenches, on the front lines, or in any part of our land is entitled to write in the name of someone dear to him, be it a brother, wife or lover, mother or illegitimate child, or an old friend, or a far-off person who in some way is close to his heart, and he may do as he likes with the sum that the state puts at the disposal of its combatants. ${ }^{28}$.

27 Undated note, presumably from the late spring of 1918, in Archivio Centrale dello Stato (ACS), Carte Nitti, b. 19, f. 49. The INA's propaganda campaign-one can glean from the note-had been massive: two million policies had already been sent to the front, and INA officials were dispatched to hold talks explaining how they worked and pass out publicity material.

${ }^{28}$ This quotation from Nitti, for which the original source cannot be traced, can be found in the documents made available online by the historical archive of the INA; see http://www.alleanza.it/Chi-siamo/La-storia/Il-conflitto-e-la-ripresa/Polizze-combattenti/ (last accessed August 28, 2018). 
And General Armando Diaz ${ }^{29}$, in a telegram addressed to the troops meant to publicize the distribution of policies at the front (where they were actually signed), reminded them that enlisted men and officers could freely choose would was to receive these sums in the event of their death, "even without regard for the civil code, allocating them as they see fit according to the pledges made in their hearts and sentiments." ${ }^{30}$.

The discussion and reform of war pensions and the introduction of free life insurance for combatants showed the strategic importance and driving role that the exigencies of mass mobilization played in promoting and accelerating new forms of social protection. ${ }^{31}$ Nevertheless, the attempt to transform and expand welfare through the creation of the new Ministry of Military Assistance, aimed at giving the state a more active role alongside traditional, but clearly insufficient, forms of private or religious charity, went beyond the obvious - and in some ways primary - function of rewarding the sacrifices made by the nation at arms. The editors of the aforecited commemorative volume of 1919 made some unquestionably bold statements about the new model of state that seemed to be emerging at the end of the war:

Out of the tragic story of this terrible conflict [....] Italian lawmakers have gradually charted a luminous path in which ethical values shine brightly and government takes on a more perfect and advanced form. The state of law that was considered the most elevated form of state before the war [...] has suddenly been overtaken and surpassed by the loftiest of concepts: the state of law and social welfare. ${ }^{32}$

Without drawing any exaggerated conclusions about its lineage, it could be useful to point out that the expression stato giuridico sociale ("state of law and social welfare," or "social state of law") used here in an institutional context by two ordinary bureaucrats, seems to significantly foreshadow certain labels that would appear in the better-known, highly turbu-

${ }^{29}$ Diaz was appointed chief of staff of the Italian army after the defeat at Caporetto.

${ }_{30}$ Ministero per l'Assistenza Militare, 1919, p. 339.

31 The connection between mass recruitment and the welfare policies that emerged from World War I has been pointed out by A. Rasmussen, 2016

32 Ibid., p. 26. Italics are in the original. This expression was borrowed from the words that Minister of Military Assistance Ugo Da Como used on October 12, 1919 at the Third Inter-Allied Conference on Disabled Veterans, held in Rome. On that occasion, Da Como said: "The new state of law and social welfare, to which all democracies aspire, has grown out of the war and replaces the former model, taking human fellowship as its foundation." 
lent climate of Weimar Germany only in the late 1920s, with the expression Sozialer Rechtsstaat, coined by legal scholars such as Hermann Heller and Franz Neumann. ${ }^{33}$

And so by the end of 1919, bureaucrats at the Ministry of Military Assistance were in any case well aware that they were looking at an obvious evolution in the social role of the state, which seemed to mark the decline of the traditional, now obsolete Liberal concept of carità legale ("legal charities," private organizations with state oversight) in favor of the new "government assistance." This awareness could also be seen in their citation of laws previously passed by the administrations of Francesco Crispi and Giovanni Giolitti, as if to explicitly emphasize the break with such perspectives that came about with the foundation of the new ministry. While according to Crispi, in 1889 , it was the task "of local organizations, in exceptional cases even with governmental aid, to provide for the support of those unable to work," ${ }^{34}$ Giolitti took a step forward a few years later, in 1904, envisioning a greater-albeit still subsidiaryrole for the state and declaring that "first and foremost, public assistance is a natural obligation of Society, which must provide for it with all means at its disposal. Only as a second line of action must the state step in, making up for any shortcomings in social assistance." 35 The war therefore seemed to have led the government to lay aside the role of costar and claim the spotlight in welfare policy.

\section{Social insurance, citizenship rights, and the masses}

The new social rights did not spring solely from the need to respond to and reward the sacrifices of the nation at arms; they were not only a response to mass recruitment and the new working-class slant of the military. It was the very nature of modern, total warfare that brought the lower classes into the life of the nation in a way that could no longer be halted.

\footnotetext{
33 Scheuerman, 1994, p. 257.

34 Francesco Crispi, Report presenting law no. 6144 of June 30, 1889, in Ministero per l'Assistenza Militare, 1919, p. 88.

35 Giovanni Giolitti, report presenting law on charities, Law no. 390 of July 18, 1904, in Ministero per l'Assistenza Militare 1919, p. 88. The subsidiary role of the state in the field of welfare that Giolitti proposed at the turn of the century was in perfect harmony with the ideas put forth in the period by the Social Catholic sector; see Tacchi, 2015.
} 
In a speech before the Chamber of Deputies in the fall of 1917, Treasury Minister Nitti acknowledged that the "trenches and fields"- military service and agricultural labor-both called for what the statesman tellingly terms "full rights of citizenship":

And those masses of men who, in the trenches and in the fields, have most suffered from the war, when they return, will return to invoke their full rights of citizenship, and now that they have struck out on the great path of history, no one can divert them from it. ${ }^{36}$

As his biographer has pointed out, Nitti, "who in his cultural background and outlook nevertheless remained a product of Liberal-era positivism, was one of the few to quickly grasp the inherent transformative power of the war and point out the need to create new tools of analysis and planning." ${ }^{37}$ The provisions regarding war insurance and assistance, which were unquestionably a product of the acceleration triggered by the conflict, ushered the lower classes into the world of insurance en masse, definitively altering the approaches and theories that had characterized debate on these issues up to then. As pointed out in early 1918 by the Socialist Rinaldo Rigola, secretary of the Confederazione Generale del Lavoro (CGdL - General Confederation of Labor), one important principle of insurance in particular-its obligatory nature-became definitively established during the war:

While before the war it was still possible to argue about whether insurance should be voluntary or obligatory, such arguments can now be considered definitively behind us. Workers and industrialists, statesmen and experts on societal health, economists and sanitarians, all agree now that insurance must be made obligatory, and be built around three

36 Atti Parliamentari, Camera dei Deputati, XXIV Legislatura, speech of October 20, 1917 , p. 14792. Georges Clemenceau used basically analogous words in his famous speech to the French Parliament upon taking office, exactly one month later: "Ces Français que nous fûmes contraints de jeter dans la bataille, ils ont des droits sur nous."

37 Barbagallo, 1984, p. 240. Nitti had voiced harsh opinions about the inadequate, conservative nature of Italy's social protection policies on more than on occasion in preceding years. See Nitti, 1953, pp. 419. Already in 1913, as Minister of Agriculture, Industry and Trade (the ministry that coordinated social policies at that time) Nitti had set up a special commission to prepare a bill for reforming and developing the outdated social legislation and to include agricolutural workers within the boundaries of the social state. See Moses, pp. 179-180. 
forms of contribution, from workers, employers, and the state. The notion of obligatory insurance has won hands-down. ${ }^{38}$

The sometimes vehement differences of opinion that had pitted supporters of voluntary insurance against proponents of obligatory insurance for decades had melted away upon encountering the new demands imposed by the war. In the face of the circumstances, obligatory insurance had indeed "won hands-down."

The first measure in the realm of insurance that marked a definite break with the past was introduced by the Boselli administration in August 1917; it made accident insurance coverage obligatory for farm workers. ${ }^{39}$ This initiative not only put agricultural workers in the same position as industrial workers by making insurance equally obligatory for the former, ${ }^{40}$ but introduced into Italian welfare law for the first time the modern principle that services should be automatic in nature: the right to compensation was no longer linked to the contributions paid in (exclusively by the employer) but was automatically triggered by the mere fact of belonging to a profession covered by the decree. For the first time, the law brought some nine million farm workers into the world of social protection, making insurance public and obligatory. ${ }^{41}$ It took over two years from the time the degree was issued for it to enter into force, in July 1919. While sluggishness and delays in the actual application of the new measures characterized many of the welfare provisions introduced from 1917 to 1919 (it was not only necessary to pass implementation laws, but to set up entire new bureaucratic and administrative frameworks, often from scratch), the lag in application of the laws regarding accident insurance for farm workers was due to predictable but forceful opposition from farm owners. Meeting in Rome in January 1918, representatives of the comizi

38 Rigola, 1918,pp. 1.

39 The first attempt to present legislation in this field was made by Liberal senator Emilio Conti in 1907; see Atti Parlamentari, Senato, Legisl. XXII, sess. I, 1904-1907, doc. n. 440. In December 1916 a new bill was presented by Liberal MPs Borromeo D'Adda, Venino and Belotti; this proposal was then incorporated in the bill presented to the Senate by the minister of agriculture, industry and trade, Giuseppe De Nava, on March 26, 1917.

40 Already introduced, but only for industrial workers, in 1898.

41 The decree regarded agricultural laborers of both sexes aged nine to seventy-five, both permanent and temporary, including "landowners, mezzadri, tenant farmers, their wives and children, both natural and legitimate." 
agrari (farmers' assemblies), the chambers of commerce, and agricultural associations, along with members of Parliament and individual landowners, drafted a sort of manifesto against the law, well aware that "the decree would have a major impact on relations between workers and owners, both politically and owing to its financial repercussions." 42 The main point of conflict was the fact that the implementation law called for a monopoly on the centralized public management of accident insurance, entrusted to the newly founded Cassa Nazionale Infortuni (CNI - National Accident Fund). ${ }^{43}$ During discussion of the regulatory framework, the CNI's monopoly was instead strongly supported by Socialist trade union representatives such as Argentina Altobelli and Ludovico D'Aragona, well aware that employers had total control over the mutual aid societies active in the sector. ${ }^{44}$ Pressure from agriculturalists, which even reached the desk of the prime minister ${ }^{45}$ did not change the substance of the final provision. ${ }^{46}$

With regard to accident insurance, it is useful to point out that the concept of "professional risk," which in Italy, too, had served as the basis for early insurance schemes since the late nineteenth century, was transferred and "exported" to the sphere of the new insurance for combatants (the principle of "professional risk" was introduced by the previously mentioned war pension reform of October 1918). This testified to the circulation and circular nature of concepts and know-how connected to labor law, a connection of which contemporaries were well aware. As noted in 1919:

42 ACS, Presidenza del Consiglio dei Ministri (PCM) 1918, f. 5.1.607.

43 Previously Cassa Nazionale d'Assicurazione per gli infortuni degli operai, founded in 1898 to manage only obligatory accident insurance for factory workers. The new CNI oversaw the operations of the sixty-nine mutual aid funds that existed at the time, which provided accident insurance locally or for specific professions.

44 The implementation measures (issued as Decree no. 1889 of November 21,1918) were drafted by a specially appointed commission at the Ministry of Industry, Trade and Labor; see Ministero per l'Industria, il Commercio e Lavoro-Direzione Generale del lavoro e della previdenza sociale-Divisione previdenza sociale, 1919.

${ }^{45}$ See the pamphlet "Dell' assicurazione obbligatoria per gl'infortuni sul lavoro in agricoltura" in ACS, PCM 1918, f. 5.1.607, which describes the positions that emerged during the meeting of January 1918, as well as a full list of the landowners' associations and individual attendees.

${ }^{46}$ Despite pressure from landowners, the Fascist government also preserved state control over the institutions managing accident insurance, which continued to be headed by the CNI. 
The aim of invoking these principles [of professional risk] in the field of war pensions as well is to find a point of contact, a link, between the laws on accident insurance and those on war pensions. There can be no question that the two institutions should be seen as overlapping and, in some way, as evolving parallel to each other. As a result, progress in a nation's welfare laws must also necessarily extend to legislation regarding war and the military. And so the theory of professional risk that has developed in modern welfare legislation must necessarily have a decisive influence on reforms to the war pension system, where a parallel theory has taken shape: the idea of combat risk. ${ }^{47}$

The exigencies of total mobilization had blurred the boundaries between soldiers and workers, and injured soldiers "were to be seen as workers on the battlefront." More generally, in those years the very concept of social risk had been transformed and expanded; in Italy, as in other countries, the experience of the war "gave way to new understandings about risk as a general social problem." 48

It was not until the end of the war that the second landmark measure regarding social insurance would be passed. In November 1918, just after the war's end, the Minister of Agriculture, Industry, and Commerce, Augusto Ciuffelli, presented the Chamber of Deputies with the administration's "Provvedimenti per l'assicurazione obbligatoria contro la invalidità e vecchiaia" ("Provisions for obligatory insurance against disability and old age"). ${ }^{49}$ In his report illustrating the bill, the minister described the less than stellar results that had been achieved in two decades of voluntary insurance, since in 1915 only 532,016 workers ${ }^{50}$ were voluntarily enrolled in the National Insurance Fund, just 3\% of the active working population. ${ }^{51}$ As one reads in the minister's long report, the Italian government had carried out a preparatory phase of in-depth study, taking as a model and reference the laws already introduced in this realm in Germany, France, the Netherlands, Spain, Great Britain, Romania, and Swit-

47 Ministero per l'Assistenza Militare, 1919, p. 591.

48 Moses 2018, p. 238 e p. 214.

49 The step that preceded this provision came in April 1917, when registration with the Cassa Nazionale di Previdenza per Assicurazione Invalidità e Vecchiaia was made obligatory for workers at factories "auxiliary to the war effort." Up to then, this registration had been strictly voluntary even for industrial workers.

50 INPS, 1962, p. 322.

51 Percentage calculated based on data from the general census of 1911. See Annali di Statistica, 2010, p. 191. 
zerland. Looking beyond its complex technical aspects, the underlying political motivations of the government initiative were clearly expressed in the minister's final words:

Honorable colleagues! The matter presented for parliamentary examination with this bill is a weighty one: the questions it raises are of an arduous and complex nature. But the purpose is so lofty that every human heart must embrace it: fostering a sense of security in the souls of workers, protecting the workforce for the benefit of society and families whenever possible, intervening with the preventive measures and remedies that experts advise, making sure that when productive energies flag due to age or infirmity, there be at least the necessary minimum for survival: this is what our administration desires, this is what our country now unanimously demands. Other nations, preceding Italy in this arduous initiative, have already shown how it is possible to fairly and effectively protect workers against disability and age, and now this problem occupies our souls and minds as well: today, the time is ripe, and after the toil and glory of the great war, with Italy's awareness of her duties to her people having grown, this matter presents itself for the first time for analysis by Parliament. So let this legislature, which has led Italy on its own natural terms, have the honor of undertaking this great task of peace and social justice, ensuring due protection to elderly and disabled workers. ${ }^{52}$

The labor representatives on the board of the CNP also expressed full approval of the project, stating that it even surpassed "the measures laid out by foreign legislation in this regard, and the requests formulated by Italian workers before the war." 53 The final days of the Orlando administration nevertheless threatened to drag the provision into oblivion, and it was above all due to the prime minister's pressure on CNP leadership ${ }^{54}$ that the bill was translated into Decree no. 603 of April 21,

52 Ciuffelli's report is published in INPS, 1962, p. 319 et seq.

53 Conference of labor representatives on the board of the Cassa Nazionale di Previdenza to examine the bill on obligatory disability and old age insurance, Rome, February 8-10, 1919, in INPS, 1962, p. 189.

${ }^{54}$ Regarding this pressure, exercised in the winter of 1919 by Cesare Ferrero di Cambiano (president of the Cassa Nazionale di Previdenza since 1904) and by Meuccio Ruini, undersecretary of the Ministry of Industry, Trade, and Labor, see ACS, PCM, 1919, 5.4.313, letters of March 6 and 16, 1919. 
1919. ${ }^{55}$ The provision opened up the possibility of an old-age pension for some twelve million workers, a quantitative and qualitative leap of obvious breadth and significance, involving factory and farm workers, including tenant farmers and mezzadri (sharecroppers), but also white-collar workers and shopkeepers with low incomes. It thus marked the first decisive step toward the creation of a broad, cross-class system of collective redistribution, the basis for developing a modern welfare system. It was with some satisfaction, a few months after the bill's passage, that Meuccio Ruini (a member of the Radical Party who was then undersecretary to the Ministry of Agriculture, Industry, and Commerce), speaking before the High Counsel on Social Insurance, ${ }^{56}$ which had met to prepare implementation measures for the decree, noted how much progress the country had made in the field of social insurance in two intense years of activity:

Italy has shown great courage in passing this law. To be sure, she has risen from last place and now occupies the vanguard for social insurance. No other country offers such broad and vast services in this field. With the set of provisions already in force for accidents, disability, and unemployment, to be rounded out only with regard to illness, we have thus created a full, integral edifice of insurance coverage which will grow to be ever more coordinated and unified. The worker's right to social assistance, in all cases, is guaranteed. His old age is safe from penury and indigence, he can be certain to receive proper support in times of involuntary unemployment, and soon enough, there will also be provisions for what most concerns the working classes, that is, aid in the event of illness. ${ }^{57}$

55 Workers became entitled to a pension upon turning sixty-five; the contributions (divided between the worker and employer) were paid by the employer, who detracted the worker's portion from his or her pay; the insurance policy was handled by the Cassa Nazionale per le Assicurazioni Sociali (CNAS), the new name of the previous Cassa Nazionale di Previdenza, and its local branches. The state contributed fifty million lire per annum to CNAS expenses and 100 lire to the liquidation of each pension. Insurance was obligatory for foreign workers as well, although in their case there was no government contribution (except for those from countries which had signed bilateral agreements with reciprocal provisions for emigrant workers).

${ }^{56}$ An advisory body dealing with labor and insurance established at the Ministry of Agriculture, Industry and Trade in 1869.

57 Minutes of the Consiglio Superiore della Previdenza e delle Assicurazioni, meeting of December 2, 1919, in INPS, 1962, p. 352. 
Ruini's call to provide for "what most concerns the working classes," health insurance, nevertheless proved to be the most significant, serious gap in welfare coverage with which Italy came out of the war. There were plenty of proposals and projects, and they included some of the most ambitious and innovative ideas developed during the war. On the very day that the provision introducing obligatory accident insurance for agricultural workers was passed, in August 1917, a commission was appointed to prepare and present a plan for introducing obligatory health insurance; those behind the project clearly realized that accidents and illness were connected and complementary, and that a single strategy had to be put together to deal with the two issues as an integrated whole. ${ }^{58}$ The commission, which came to be known as the Abbiate Commission (after its leading member, the Liberal Democrat MP Mario Abbiate ${ }^{59}$ ), worked for over two years on a project that mapped out a sort of national healthcare service ante litteram ${ }^{60}$ : a proto-universalist model- "insurance is to be extended to all citizens" 61 - that would offer broad healthcare coverage (medical, surgical, and obstetrical care, and pharmaceuticals) to "all workers in the employ of others": laborers, apprentices, shop boys, home workers, domestic staff, tenant farmers and mezzadri, but also white-collar workers and professionals. ${ }^{62}$ Healthcare and accident insurance, but also maternity coverage, would come together in a single insurance plan overseen by a single centralized agency, the Cassa Nazionale per le Assicurazioni Sociali (National Fund for Social Insurance), which was to operate locally through the Social Insurance Institutes. The system was funded by joint contributions from workers, employers, and the state, with considerable aid from municipalities and local charities, whose func-

58 In this regard, see also the parliamentary discussions of the previous month: Atti Parlamentari, Camera dei Deputati-Discussioni, session of July 12, 1917, p. 14329 et seq.

59 Mario Abbiate, the first minister of labor and social insurance, is still a little-known figure, but was central to the development of welfare in the first two decades of the twentieth century. See Cassetti, Quaranta, Marucco (et al.), 2015.

60 The commission, which operated under the Ministry of Agriculture, Industry, and Trade, and later the newly founded Ministry of Labor and Social Insurance, left minutes of its work; see Ministero dell'Industria, commercio e lavoro-Direzione generale della previdenza sociale, 1920; Ministero per il Lavoro e la Previdenza sociale-Direzione generale della previdenza sociale, 1921.

${ }^{61}$ Ministero per il Lavoro e la Previdenza sociale-Direzione generale della previdenza sociale, 1921, p. 205.

${ }^{62}$ If their income was under the threshold set by the plan, respectively 350 lire per month and 4200 per annum. 
tions and autonomy (financial and otherwise) were thus profoundly reinterpreted. The plan would have radically remodeled the fragmented, irregular world of hospitals and healthcare, especially at the local level, and more generally, the sphere of public and private charity, which in Italy was historically dominated by the vast constellation of Opere Pie, many of them owned and operated by the Church. ${ }^{63}$ During the commission meetings, Abbiate himself spoke in defense of the "unified exercise of assistance," a very innovative principle for the time, which shows the desire for reform underlying the initiative and how it radically modernized the insurance sector, not only from an organizational and financial standpoint, but from a social one as well. While the goals of the reform were expressed in terms still rooted in the concept of social regulation, its proposals were aimed at reformulating the right to assistance, in part as a kind of civic and social edification:

There are societal reasons for unifying assistance. This union reflects a shift in our spirit, a democratic shift: not all at once, since that is not possible, but gradually, every form of charity in human life is disappearing to make way for assistance. When we reach the point of abolishing all that is charity and transforming it into some form of insurance, we will not only have a policy that uplifts our fellow man, but will have carried out a great task of public education, because replacing charity with insurance is edifying for the masses. And so once this financial, societal, beneficial action is achieved, and implemented through a vast governmental body, we will have improved not only our health, but our society. ${ }^{64}$

\section{A "silent revolution"}

The war has silently brought about a great revolution. On the morrow of this war, we find ourselves in a rather singular position in history: we find the revolution already carried out and [...] must ask ourselves if its effects are to be kept in place. This extreme form of state intervention, better known under the German name of state socialism,

63 Farrell-Vinay, 1997.

${ }^{64}$ Ministero per il Lavoro e la Previdenza sociale-Direzione generale della previdenza sociale, 1921, p. 189. 
has been put into operation in many countries [...] The phenomenon must therefore be studied, to see whether the laws through which it is manifested are to be preserved or not. For if the revolution was not the result, so far as one can see, of conscious planning, the counter-revolution at least ought to be. The first principle of any revision or reform is to clearly understand and describe the change that has been produced, the regime that has been established. ${ }^{65}$

In this famous inaugural lecture for the 1919-1920 academic year, Filippo Vassalli, a professor of civil law at the University of Genoa, insightfully grasped the breadth and significance of the changes that the war had brought about in the functions and role of the state, even in Italy. In the famous scholar's view, it was a process whose effects could be compared to a full-fledged "revolution," although Vassalli saw it as not always derived from "conscious planning," but rather from an almost unavoidable sequence of events set in motion by the extraordinary nature of the war and its demands.

The results, effects, and problematic aspects of this revolution would end up being dealt with above all by the two administrations headed by Francesco Saverio Nitti ${ }^{66}$ and Giovanni Giolitti. ${ }^{67}$ To date, there has been no study of the postwar transition phase that focuses on the impact of the new assistance and insurance measures on government institutions, on the central and local bureaucratic apparatus, on public opinion, and on organized interests as a whole. Nor has there been a sufficient exploration of possible links between the choices that were made and the rise of Fascism, despite the wealth of studies focused on the Liberal state and the rise of Mussolini's movement. ${ }^{68}$

It would be pivotally important to find evidence "from below" of to what degree veterans, farm workers, factory workers, and white-collar workers were aware of possessing these new rights. The fact that the welfare measures introduced during the war were perceived as full-fledged rights clearly emerges, for example, from the wording employed as early

65 Vassalli, 1919, p. 1 et seq.

66 June 1919-June 1920.

67 June 1920-June 1921

${ }^{68}$ One is reminded of a suggestion made many years ago by Arnaldo Cherubini: "Among the factors that gave rise to Fascism, I do not believe one should overlook a system of social insurance that was moderate (or rather, "cautious") yet socialist in inspiration, and all of its political and economic consequences." Cherubini, 1974,p. 802. 
as October 1918 by the Federazione Italiana delle Società di Mutuo Soccorso e delle Cooperative (Italian Federation of Mutual Aid Societies and Cooperatives), at a congress jointly organized with the General Confederation of Labor:

The working class does not ask, nor does it mean to ask, for obligatory insurance against illness, disability, and old age as a charitable solution to social problems that have heretofore remained unresolved, but as an expression of rights which have long been earned, though heretofore in vain, in the harsh and glorious arena of work and social production. ${ }^{69}$

Millions of citizens, mostly from working-class or peasant backgrounds, could now legitimately ask government institutions to provide compensation for the damages they had incurred and to recognize the new rights they now held. For many it was their first experience (not always an easy one) of interacting with government offices, but was often marked by delays, rejected applications, and unanswered letters. These problems, but also the unprecedented public awareness of possessing specific rights, were highlighted by a column that in July 1916 began to appear in Avanti!, the newspaper of the Italian Socialist Party. Titled Questionario di guerra ("War Questions"), it guided thousands of readers-enlisted men, veterans, and their families - through this "daunting bureaucracy," 70 helping to explain the complicated administrative procedures they had to follow in order to receive the compensation envisioned by law. These were "rights, not charity,"71 wrote "Travet Rosso" (Red Travet) - the name used by the anonymous columnist ${ }^{72}$ - who by October of 1919 had answered some 10,354 questions from people all across the country.

Nevertheless, in the complex transition from war to peace, the first victim of demobilization was one of the most significant institutional in-

69 The Congress on Social Insurance, organized by the Federazione Italiana delle Società di Mutuo Soccorso e delle Cooperative, in partnership with the Confederazione Generale del Lavoro, Turin, October 6-7, 1918, now in INPS, 1962, p. 189. Italics are this author's.

70 Avanti!, July 16, 1916, p. 2. I would like to thank Giulio Francisci for pointing out this reference.

71 Avanti!, July 31, 1916, p. 2.

72 "Travet" comes from the title of an 1863 comedy, Le miserie del Signor Travet, "Mister Travet's miseries"; it became a byword for a punctilious low-level clerk. "Rosso" (Red) alludes to the traditional color of the Socialist Party. 
novations brought about by the conflict, and the primary contact for millions of veterans and families seeking recognition of their sacrifices and injuries: the Ministry of Military Assistance. Not only was the short-lived bureau never transformed, as some had hoped, into a broader, more universal ministry of welfare - although over the course of 1919, this idea was floated again by more than one party ${ }^{73}$ - but the institution into which the Reformist Socialist Bissoliti had channeled his efforts and which, in October 1919, could boast of having provided support to some 7,500,000 people in just two years of activity, ${ }^{74}$ was dismantled. This came about by order of Prime Minister Nitti in November $1919^{75}$ (earlier than envisioned by the law that established it). ${ }^{76}$ Military assistance was demoted to the more modest rank of a General Directorate, under the guidance and careful financial oversight of the Treasury Ministry. Nitti's decision to downgrade the bureau reflected a clash in policy and strategy that had set him against Bissolati and his ministry since the previous year. A note from Nitti himself, which can be dated to the late summer of $1919,{ }^{77}$ shows his intention to dissolve the Ministry of Military Assistance, which the new prime minister saw as just one of the many unfortunate examples of how new government offices had mushroomed, as if by parthenogenesis, as a result of the mobilization effort. In his view, rooting out such excesses in the state apparatus was essential if he was to efficiently manage the demobilization phase. Yet even more significant, perhaps, was his fear that the policies of the Ministry of Military Assistance would foster a pernicious

73 See the proposal by Mario Pietravalle, 1919, p. 104. The article cited the decisions voted on in January 1919 by Section XXIV (Societal Health) and Section XXV (Civil Assistance) of the Royal Commission on Postwar Problems, set up by the Orlando administration on March 21, 1918 to tackle the many sticking points in the transition from war to peace. The Royal Commission did its work through subcommissions; Subcommission 10 (Social Legislation and Insurance) known as the Rava Commissione after its chairman Senator Luigi Rava, drew up an ambitious program of reforms that were never implemented. See A. Rapini, 2012.

74 Ministero per l'Assistenza Militare, 1919, p. 30.

75 Decree no. 2200 of November 25, 1919.

76 The decree that founded it specified the temporary, emergency-related nature of the ministry, which was to remain in operation only "for the duration of the war, and for one year after the declaration of peace."

77 ACS, Carte Nitti, b. 12, f. 28. Nitti's typewritten note is headed "main goals to be achieved"; it presents a sort of wish list with regard to a governmental reshuffling that - he hoped-would finally lead a "bourgeois" to the head of the War Ministry and involve a direct collaboration with the Socialists after the elections. 
culture of dependency, barely disguised by a gloss of patriotic rhetoric. These concerns, and this attitude, clearly emerged from a speech that Nitti gave to the Chamber of Deputies in November 1918:

We have modified the laws on war pensions, giving them greater breadth and making up for some shortcomings, but as I warned last year, it is above all necessary to avoid creating a dependent population. $^{78}$

Nitti's vision of reform for the post-war period had a productivist slant and called for a parallel overhaul of the state bureaucracy, to create an elite of highly skilled public officials. A top-down model of action was therefore to be adopted, backed up by an efficient administrative framework. In Nitti's view, the Opera Nazionale Combattenti (ONC - National Institute for Combatants) - which, not coincidentally, was founded in December 1917, in conjunction with the measure introducing free life insurance for those in the military-was supposed to become the main point of contact between veterans and the state, passing on the productivitycentered impulse that drove his postwar strategy of economic revitalization. The ONC would take up the task of putting veterans back to work, by training them for new jobs, creating cooperatives, and allotting uncultivated land. As one reads in the previously cited celebratory volume published by the Ministry of Military Assistance, the ONC was meant to combine assistance to veterans with its primary function of "encouraging more elevated and fertile economic and social activities." 79 By contrast, the Ministry of Military Assistance was seen by Nitti as "a merely quantitative, dependency-centered expansion of government, without any apparent value within the project of reform he had conceived." The divide "between the aid-oriented state of the Reformist Socialist Bissolati and the production-oriented state of the Liberal Nitti could not have been clearer or more unbridgeable," 80 even though the same positivist background shaped the outlook and the reform strategies of both men. As some have pointed out, at its heart Nitti's positivism had "an all-engulfing quality, convinced as he was that there was only one reality and only one correct

78 Atti parlamentari, Camera dei deputati, XXIV Legislatura, speech by Francesco Saverio Nitti, December 26, 1918, p. 17670.

79 Ministero per l'Assistenza Militare, 1919, p. 392.

${ }^{80}$ Quagliaroli, 2018,p. 162. 
way to look at it. And as insightful as he often was in arriving at an incisive analysis of the situations that presented themselves to him, he was, on the whole, ill-prepared to understand the different motivations and different values that underlay other interpretations, choices, actions, and decisions." 81

The downgrading of the Ministry of Military Assistance to a general directorate nonetheless ended up creating even worse delays in processing the hundreds of thousands of pension applications (some 913,112 had been presented by June $1920^{82}$ ), and the problems resulting from what was already a chronic scarcity of manpower and resources became ever more obvious. Moreover, these problems had existed since the creation of the Ministry of Military Assistance in November 1917 and derived from the state of emergency in which it was established, since it could not build on any solid, preexisting administrative structure. Nitti's choice to dissolve the ministry was therefore not without consequences, in both practical and symbolic terms: for thousands of veterans and their families, this inevitably overworked bureaucracy, full of red tape, was the first barrier that seemed to scuttle their newly acquired rights. ${ }^{83}$

Nevertheless, realizing that veterans' issues were a strategic element in the fragile political and social equilibrium of the post-war period, and conscious of their electoral implications, the second Nitti administration-under pressure from both veterans' groups and political forces like the Socialist Party-returned to the problem of insurance measures for former combatants, passing a retroactive extension of the free life insurance policy to include those who had fought between May 24, 1915 and December 1917 and up to then had been excluded from the provision. ${ }^{84}$

The period of the Nitti administration also witnessed the last innovative measure to be passed in the months just after the war: the introduction of obligatory unemployment insurance, which put Italy at the leading edge of European welfare policies. Aside from a British law of 1911 that had introduced an early, experimental kind of obligatory unemployment

81 Barbagallo, 1984, p. 228.

82 Barbagallo, 1984, p. 231

${ }^{83}$ Regarding the difficulties that many veterans encountered in trying to obtain a war pension, see the many letters and first-hand accounts in Quagliaroli, 2018, pp. 215-250.

${ }^{84}$ Decree no. 738 of June 7,1920 . As with other measures, it took a year and a half for the implementation law (decree no. 252 of January 22, 1922) to be passed so it could enter into force. 
insurance limited to certain categories of workers, and the Soviet laws of 1917, Italy was the first nation to introduce a large-scale system of obligatory unemployment insurance..$^{85}$ The Italian laws also came a step ahead of the recommendations made by the International Labour Organization at its first conference in November $1919 .{ }^{86}$

The end of the wartime economy, the slow reconversion of industry, and the flood of male citizens returning from the front made mass unemployment the new specter of the postwar period, in Italy and elsewhere. At the end of 1919 there were estimated to be about 300,000 people out of work in Italy, mostly concentrated in northern and central regions, but the real figure was probably much higher ${ }^{87}$ In January 1919, the Orlando administration passed its first measure aimed at this problem, creating a system of monetary support for unemployed workers. ${ }^{88}$ It was granted to factory and farm workers who were unemployed between January and December 1919. There were also supplementary benefits for families with dependent minors and, in keeping with past regulations, the decree explicitly included "irregular families," that is, households in which a woman cohabited with the worker receiving benefits. The measure passed in January was meant to be a temporary stop-gap, but the gravity of the phenomenon required solutions that would tackle the problem in the middle to long term. In October 1919 the Nitti administration therefore passed a plan for obligatory unemployment insurance - the only example of this in Europe at the time-covering industrial and agricultural workers and white-collar employees of both sexes, aged fifteen to sixty-five. ${ }^{89}$ The benefits, whose payment was dependent on the worker's registration with a job placement office, were funded by joint contributions from workers and employers, with an annual government contribution of fifty million lire. The provision, a radical break with Liberal policies that traditionally did little to protect those who lost their jobs, prompted vehement reactions from farm owners. They strongly opposed its application, and managed to

85 Alberti, 2016, p. 74. For a reconstruction of the genesis and first few years of implementation of this measure, see G. Francisci, 2018.

${ }^{86}$ Liebeskind Sauthier, 2013.

87 Employment statistics were based on the number of people registered with job placement offices and the number of workers receiving benefit payments, so they were partial and patchy, because there were many more placement offices in Northern Italy.

${ }^{88}$ Decree no. 6 of January 5, 1919.

89 Decree no. 2214 of October 19, 1919. It did not include domestic workers, civil servants, or those who worked from home. 
have the first contributions postponed to July 1920 (for factory owners, on the other hand, the date of January 1, 1920 stayed in place). But this concession did not dampen the resistance of agriculturalists, who began to send pressing demands for the abolition of the measure to the Prime Minister's office and to the Ministry of Labor and Social Insurance-which kept changing hands until 1922, seriously undermining the effectiveness of the law. ${ }^{90}$

The post-war administrations also found themselves grappling with the complicated problem of how to inform possible beneficiaries about the new provisions that had been introduced. Most of the provisions that began to be passed in the fall of 1917 entered into force only many months later-this was true of the law on accident insurance in agriculture, which became operative in May 1919, or the one on obligatory old age and health insurance, which entered into force in July 1920. The postwar governments thus also had to deal with this problem, which was anything but secondary, since the actuarial sustainability of the insurance programs was closely tied to the number of people participating and the regular payment of contributions. It was necessary to reach out to a population unschooled about the complex technical aspects of the law - and also unschooled in general, more often than not. This was a particularly delicate problem, especially when it came to farm workers, who were being ushered for the first time into the world of insurance. We can find evidence of this effort, for example, in a curious booklet published in Bari that began to be distributed in 1920, titled L'assicurazione invalidità e vecchiaia e $i$ lavoratori della terra: Dialogo tra un professore ed alcuni contadini (Disability and Old-Age Pensions for Those who Work the Land: Dialogue between a Professor and Several Peasant Farmers). Using the traditional but effective question-and-answer structure of a catechism lesson, it explained the details of the law in simple words, as if speaking to a group of puzzled country people. The propaganda and outreach initiative also served obvious political ends, as we can see from this letter sent to Prime Minister Nitti in April 1920:

90 Regarding the protests of farm owners, see ACS, PCM, 1920, 6.2.166; Archivio Storico Confindustria, Serie 0011: Direttore generale: Carte a firma di Giovanni Balella, busta 113, fascicolo 341 "Assicurazioni sociali in generale" and busta 120, fascicolo 351 "Assicurazione contro la disoccupazione." 
In order to bring workers closer to the state by helping them see it as a friend and protector, to provide comfort to the worthy as part of the demobilization effort, and to encourage registration among those who are apprehensive or indifferent, it would be very useful to familiarize the population with the great initiative of state-funded worker pensions, and with all that is currently being done on behalf of the working classes. Spreading these healthy facts and brotherly propaganda would help keep the peace..$^{91}$

The path to application in the period just after the war proved long and difficult for some of the most significant insurance measures that had been adopted, revealing the sluggish and awkward way in which Parliament, returning to work after the long period during the war when it had transferred full powers to the administration, tackled the many new issues that had arisen in wartime. One example was the April 1919 decree (and its implementation law) that introduced obligatory insurance against disability and old age. Presented to the Chamber of Deputies for conversion into law by Labor Ministers Dante Ferraris and Arturo Lariola (respectively on February 5, 1920 and June 25, 1921), the measure never received the necessary ratification from Parliament, and was thus in danger of becoming inapplicable. This technical problem was eventually settled by the Fascist government in $1923 .^{92}$

More specifically, one of the questions left to be resolved in the postwar transition phase was health insurance, which was made even more urgent by the fact that a system of healthcare had already existed for some time in the new provinces recently annexed by Italy. And the virulence with which the "Spanish flu" struck the country from the fall of 1918 to the winter of 1919 (Italy had one of the highest mortality rates in Europe) had only highlighted the failings of healthcare. ${ }^{93}$ The Abbiate Commission, entrusted with preparing the reform, pre-

91 ACS, PCM, 1920, f. 6.2.69. It was sent by Vittorio Cottafavi, a member of Parliament in the Liberal-Constitutional group, who came from a rich family of landowners near Modena.

92 By passing Decree no. 3184 of December 30, 1923. The implementation law, approved through the Decree of February 29, 1920, was definitively passed only under Fascism (Decree no. 1422 of August 28, 1924). The decree of August 1917 that made accident insurance obligatory met with similar hitches (after various changes it was passed by the Fascists as Law no. 473 of April 17, 1925).

93 Mortara, 1925. 
sented its conclusions to the Nitti administration in December 1919, after two years of work. This plan, we are told, was "subjected to merciless criticism" 94 and set aside before it could even be presented for parliamentary examination. Nitti never returned to the problem of health insurance, nor did Giolitti after him. Despite continued pressure from many sides, above all from labor associations, ${ }^{95}$ the Abbiate Commission's ambitious, innovative proposals remained a dead letter, constituting the most significant Achilles' heel of the entire assistance and insurance system that came out of the war. It was a gap that Italy would take sixty years to bridge, with the creation of its national healthcare system in 1978. Due to the failure of these measures aimed at protecting workers in the event of illness, the project of constructing an integrated, coordinated, global system of social insurance became a mirage. Even by the end of 1920, all hope of "global" insurance coverage had vanished, ${ }^{96}$ and the institutional and organizational fragmentation of Italy's welfare system would be passed on to the Fascist regime, which would not only preserve but accentuate these traits.

In the final months of the Giolitti administration, one further initiative was nevertheless added to the laws already introduced. Showing significant concern for the world of agriculture - and taking into consideration the opinions and suggestions of laborer and tenant farmer groups in the discussion stage-the government extended the scope of accident insurance for this sector in March 1921, tripling the previous limits of compensation and reducing the percentage of disability necessary to obtain it.$^{97}$ Giolitti's words at the dissolution of Parliament in April 1921 - "it is equally important to round out the social insurance program in a more serious, but more streamlined fashion" 98 - were an invitation to follow up on a task still seen as incomplete.

Although the drive for reform was clearly beginning to peter out, in August 1921 Parliament approved an initiative proposed under the last

94 Cherubini, 1970, p. 801

95 See the requests that the CGDL's steering committee presented at its National Conference for Social Legislation: INPS., 1962, pp. 196-198.

${ }^{96}$ Ferrera, 1993, p. 231. In February 1921, the National Meeting of the Confederazione Generale dell'Agricoltura took a strong stance against the "deplorable lumping together" of all assistance programs For the meeting resolutions, see INPS, 1962, pp. 193-195.

${ }^{97}$ Law no. 297 of March 24, 1921. The certified impairment of the laborer's ability to work that was necessary in order to receive compensation was lowered from $15 \%$ to $10 \%$.

98 INPS, 1962, p. 195. 
Giolitti administration by its labor minister, Socialist Reformist Arturo Labriola. Once again, it was aimed at veterans. Introducing for the first time a principle into Italian law that one might term "differential inclusion" (based on a system of professional categories that was soon embraced and taken to an extreme by Fascism), the provision ensured targeted job placement for veterans both in government offices and at private companies. ${ }^{99}$ In October 1917, the Opera Nazionale per gli Invalidi di Guerra (ONIG - National Institute for Disabled Veterans) was also founded, as the state agency tasked with bringing these former combatants back into the life of the nation. The measure introduced by the Italian Parliament was perfectly analogous to the Law for the Employment of the Severely Disabled passed in Germany in 1920 and the French measures introduced between 1916 and $1923^{100}$ and thus brought the country into line with other European systems of the era.

Under the last three Liberal administrations that succeeded each other between July 1921 and October 1922, the crisis in government left no room for further reforms. It is therefore particularly surprising to find one final, obscure piece of legislation - once again, a decree - that bears a curious date: October 27, 1922, five days after the March on Rome. The Facta administration, which would remain in office for just a few more days (the first Mussolini cabinet was officially formed on October 31), passed a measure with far-reaching consequences; it extended the scope of disability and old age pensions to cover new beneficiaries compared to the law passed in November 1918, including many more white collar workers, tenant farmers and mezzadri. ${ }^{101}$

99 Law no. 1321 of August 21, 1921.

100 Jackson, 1993; Romien, 2005. There is an extensive literature on veterans in other European contexts; see especially Cohen, 2001; Linker, 2011. German law required every workplace with twenty-five or more employees to hire at least one disabled veteran, and called for at least $2 \%$ of the jobs in larger workplaces to be set aside for the disabled. The Italian measure required every business with more than ten employees to hire one disabled veteran for every twenty employees or fractions of ten; the same proportion applied to government offices, with greater protective measures, in this case, for "impiegati d'ordine" (ordinary clerks) or "subalterni" (low-ranking positions), where $10 \%$ and $20 \%$, respectively, of the total hirees in that category were to be disabled.

101 Decree no. 1479 of October 27, 1922. The decree raised the monthly salary threshold for obligatory old age insurance from 350 to 800 lire. Likewise, for tenant farmers and mezzadri, the average annual income threshold was raised from 3,600 to 9,000 lire. 


\section{What was passed on?}

A recently proposed timeline of key steps in the evolution of the Italian welfare state singles out the two-year period from 1917 to 1919 as the moment that it first came into being. ${ }^{102}$ Italy was the European country in which the index of social benefits grew the most in the five years from 1915 to 1920 (22.5\%, compared to $7 \%$ in the United Kingdom, for instance); ${ }^{103}$ the percentage of state spending allocated to this sphere rose from the extremely low figure of $1.56 \%$ in 1914 to $6.57 \%$ in 1919 . Neither these statistics nor the description of the measures themselves can give a full picture of what took place in that period in terms of social policy. To interpret it properly, quantitative reconstruction must give way to a closer analysis of the projects that were carried through and those that failed, shifting the focus to the dynamics of clashing interests and to the parties involved. One must look more closely at how the new insurance and assistance frameworks that emerged in that period functionedfrom the Cassa Nazionale delle Assicurazioni Sociali, to the ONC and the ONIG, on which studies are still lacking. ${ }^{104}$ It is worth looking at how the new laws were applied, both locally and in the dialogue between the state's central and peripheral offices, ${ }^{105}$ not only to analyze the practical working methods of the state's new welfare services, but to see to what degree the local government interventions in the field of welfare that has been called "municipal collectivism" could be seen in the Italian context as well. ${ }^{106}$

Nevertheless, in keeping with the notion of a warfare-welfare link, one can definitely say that in Italy, too, the Great War triggered an acceleration involving a brief but intense series of reforms, which not only brought the country into line with the rest of Europe, but even moved it "from a rear guard position to one at the forefront." 107 Certain "univer-

102 Ferrera, Fargion, Jessoula, 2012.

103 Alber, 1983, p. 253.

104 The studies of the Opera Nazionale Invalidi di Guerra (Pavan Della Torre 2015) and the Opera Nazionale Combattenti (Barone, 1984) only go up to 1923. These two agencies were respectively shut down in 1976 and 1978, when the national healthcare system was created.

${ }^{105}$ An excellent reconstruction of the war pension system from this angle is provided by Quagliaroli 2018, pp.

106 Rasmussen, 2016, p. 16.

107 Ferrera, Fargion, Jessoula, 2012, p. 45. 
salist tendencies" in the expansion of social protection emerged in that phase, not only showing up in political and parliamentary debate, but taking on concrete legislative and institutional form. The principles underlying the reforms of 1917-1919 therefore helped the country take its "first step toward the creation of a single, across-the-board system of collective redistribution" 108 that would include industrial, agricultural, and self-employed workers. Without overlooking the fact that the new insurance and assistance measures were harmoniously wedded to selfserving, repressive aspects of state intervention (which have received more attention from scholars), World War I marked the true launch of Italian welfare, with "the development of bolder projects for integrating and governing the masses" and an "attempt to extend the scope of reform and assistance initiatives aimed at mediating social conflicts, to defuse them or at any rate orient their manifestations and effects." 109 As we read in one of the very few historiographic analyses formulated to date, it was "a plan of reform that was definitely insufficient compared to the real needs of postwar Italy, but nevertheless led to a very important series of welfare measures," fueling "a move to 'modernize' government and its relationship with the masses, in a clear break with the attitudes of prewar Italy." 110

The Liberal government thus passed on an updated framework of principles and its legislation, especially in the field of social insurance. The degree to which the new Fascist administration cared about these issues could be seen from the speed with which it decided to intervene: by the end of 1923, it had already made what could be called a small counter-reform.

While one can agree with those who say that the basic features of the Italian welfare state remained unchanged over the course of the $1920 \mathrm{~s},{ }^{111}$ the modifications that the new government did introduce stood out for having clear political aims that went beyond the mere objective-often

108 Ibid., p. 38.

109 Fava, 1982, p. 184.

110 Detti, 1984, p. 890.

111 Ferrera, Fargion, Jessoula 2012, p. 41. The only measure adopted in the field of insurance was an increase, in 1928, in benefits for dependent children in the calculation of old age pensions. In the field of healthcare, obligatory insurance against tuberculosis was introduced in 1927. This came at no cost to the state, since it was fully funded by equal joint contributions from workers and employers. 
emphasized in propaganda- of reining in expenditures that had ballooned on account of the war. The measures that were adopted made targeted, almost surgical amendments to the previous regulations that did not (on the surface of things) disrupt the overall system inherited from the Liberals; only the elimination of the Ministry of Labor and Social Insurance in April 1923 constituted a visible break with the recent past at the institutional level.

Not coincidentally, landowners - who had been the fiercest opponents of the reforms passed in previous years - were the ones who benefited the most from the actions of the new administration, which promptly rewarded them for their support during the rise and growth of Mussolini's movement. It was thus the agricultural world that paid the highest price when the Fascists took power. In February 1923, the degree of disability that farmworkers had to demonstrate in order to obtain compensation for work-related injuries was raised from $10 \%$ to $15 \% .{ }^{112}$ This measure also made mezzadri and tenant farmers responsible for paying a portion of the contributions that up to then had been entirely covered by their employers. The consequences of this could be seen from the radical drop in the contributions that employers were asked to pay, which fell by some $43 \%$, according to data from the CNI. ${ }^{113}$ In December 1923, two decrees that were issued on the same day turned back the clock for many people working in agriculture. ${ }^{114}$ The obligatory disability and old-age insurance that had been introduced in 1919 was eliminated for tenant farmers and mezzadri, putting them back in the situation they were in before the war. The changes to unemployment insurance, a provision that landowners had always stridently opposed, were even more drastic. As early as November 1922, the Fascist administration allowed them to suspend payment of insurance contributions for all employees. At the end of 1923, when the yearly state contribution to unemployment insurance was suspended, never to be reintroduced in the years that followed, the government exempted all farm workers from insurance obligations (they were also eliminated for domestic staff and home workers, who still made up a

112 Decree no. 432 of February 11, 1923. This decree also reduced the age range of the workers entitled to compensation, limiting it to those aged twelve to sixty-five (it had previously been from nine to seventy-five).

113 Cassa Nazionale per gli Infortuni sul lavoro, 1925, p. 113.

114 Decree no. 3158 of December 30, 1923; Decree no. 3184 of December 30, 1923. 
considerable portion of the workforce, especially among women). The most innovative feature of the Italian laws, which were the first in the world to envision unemployment insurance even for farm workers, was erased. ${ }^{115}$

The new administration also took advantage of the gaps left by the previous reforms. And so the plan for health insurance, which the last Liberal governments had already put on the back burner, was definitively dropped, and management of this fundamental sector of welfare policy was handed off to traditional charity organizations or, in the case of industrial workers, to a plethora of mutual aid funds, mostly organized at the individual company level. ${ }^{116}$ The system of mutual funds was favorably viewed by Catholics, since maintaining the traditional approach to healthcare allowed Catholic charities to preserve the role they had always played in society (delegating assistance to the Catholic Church gave it solid, lasting hegemony in this strategic sector). But it was also encouraged and supported by the Fascists, because it seemed to concretely embody the concept of class-based collaboration that was at the heart of their ideology and corporatist rhetoric.

The basic features of the legislation that redesigned the insurance system in 1923 were never updated by the regime in the years that followed. Not coincidentally, it would take another world war for Fascist leaders to reconsider their approach.

\section{Archivos y fuentes primarias impresas}

ACS, Carte Nitti, b. 12, f. 28; b. 19, f. 49

ACS, PCM, 1918, f. 5.1.607

ACS, PCM, 1919, 5.4.313

ACS, PCM, 1920, f. 6.2.69; f. 6.2.166

ARChivio Storico Confindustria, Serie 0011 Direttore generale, b. 113, f. n.341 "Assicurazioni sociali in generale"; b. 120, f. n.351 "Assicurazione contro la disoccupazione"

115 But even for the categories of workers that continued to draw unemployment insurance, the sums were quite low, given that from 1919 to 1935 the per-diem amount never changed; see Ferrera, Fargion, Jessoula, 2012, p. 55.

116 No studies currently exist of the history of mutual funds in the Fascist era; see De Grazia 1981. 
Ministero Per Il LAVOro E LA PREVIDEnZa sociale-Direzione Generale della PREVIDENZA SOCIALE, L'assicurazione obbligatoria contro le malattie. Atti della Commissione incaricata della preparazione di uno schema di disegno di legge. Parte I: Studi preparatori, relazioni, schemi di progetti di legge, Roma, 1920

Ministero Per IL LAVOro E LA PREVIDENZA SOCIALE-DireZIONE GENERALE DELla PREVIDENZA SOCIALE, L'assicurazione obbligatoria contro le malattie. Atti della Commissione incaricata della preparazione di uno schema di disegno di legge. Parte II: Verbali delle adunanze della Commissione e della Sottocommissione, Roma, 1921

Ministero PER L'Industria, il Commercio ed il lavoro, Direzione generale del lavoro e della previdenza sociale, divisione previdenza sociale, Assicurazione obbligatoria contro gli infortuni sul lavoro in agricoltura - Atti della Commissione incaricata di predisporre lo schema di regolamento, Roma, 1919

Ministero Per L'Assistenza Militare e le Pensioni di GUERra, L'assistenza di guerra in Italia, Società Anonima Poligrafica Italiana, Roma, 1919

CASSA NAZIONAle PER GLi INFORTUNi sul LAVORO, I primi sei anni dell'assicurazione obbligatoria contro gli infortuni in agricoltura nella gestione della Cassa Nazionale Infortuni, Roma, 1925,

\section{Bibliography}

AlBER, Jens, «L'espansione del welfare state in Europa occidentale: 1900-1975», Rivista italiana di Scienza Politica, 1983 (13), 2, p. 220

Alberti, Manfredi, Senza lavoro. La disoccupazione in Italia dall'Unità a oggi, Laterza, Roma-Bari 2016

Barbagallo, Federico, Francesco Saverio Nitti, Utet, Torino, 1984

BARONE, Giuseppe, «Statalismo e riformismo: L'Opera Nazionale Combattenti (1917-1923)», Studi Storici 1984, 25, no. 1, pp. 203-244

BRACCO, Barbara, La patria ferita, Giunti, Firenze 2012

Cassetti, Maurizio, Quaranta, Flavio, Marucco, Dora (et all.), Mario Abbiate. Le intuizioni oltre il suo tempo, Nuova Trauben Edizioni, Torino, 2015

CAstles, Francis G., «Black Swans and Elephants on the Move: The Impact of Emergencies on the Welfare State», Journal of European Social Policy, 20, 2010, pp. 91-101

Cermenati, Mario, «Intorno alle pensioni di guerra. Appunti, considerazioni e notizie varie», Nuova Antologia, 1918 ( $1^{\circ}$ dicembre), p. 289-294

Cherubini, Arnaldo, «Una pagina molto nota e poco conosciuta: lo schema del disegno di legge sull'assicurazione obbligatoria di malattia del dicembre 1919», La Rivista Italiana di Previdenza Sociale, 1970, n. 5, pp. 798-802 
War and the Welfare State: The Case of Italy, from WWI to Fascism

CoHEn, Daniel, The War Come Home. Disabled Veterans in Britain and Germany, 1914-1939, University of California Press, Berkeley-Los Angeles-Londra, 2001

Crocella, Carlo, Mazzonis, Filippo, L'Inchiesta parlamentare sulle spese di guerra (1920-1923), vol. I, Saggi; vol. II, Documenti: Storia della Commissione; vol. III, Documenti: Settori dell'inchiesta, Archivio Storico della Camera dei Deputati, Roma, 2002.

Da Como, Ugo, Discorso pronunciato da S.E. Ugo Da Como, ministro per l'Assistenza militare e le pensioni di guerra, in Campidoglio, Società anomia poligrafia italiana, Roma, 1919

De GraZia, Victoria, The Culture of Consent: Mass Organisation of Leisure in Fascist Italy, Cambridge University Press, 1981

DetTI, Tommaso, Stato, guerra e tubercolosi (1915-1922), in Malattia e medicina, Della Peruta, Franco (ed.), Annali Einaudi, 7, Einaudi, Torino 1984

FARrell-Vinay, Giovanna, Povertà e politica nell'Ottocento. Le opere pie nello Stato liberale, Paravia, Torino, 1997

FAvA, Andrea, «Assistenza e propaganda nel regime di guerra (1915-1918)» in ISNENGHI, Mario (ed.), Operai e contadini nella grande guerra, Il Mulino, Bologna, 1982

Ferrera, Maurizio, FArgion, Valeria, Jessoula, Matteo, Alle radici del welfare all'italiana. Origini e sviluppo di un modello sociale squilibrato, Marsilio, Venezia, 2012

Ferrera, Maurizio, Vergallo Luigi, «Guerra e politiche sociali: il caso italiano e un primo confronto con quello tedesco», Società e storia, 159, 2018, pp. 181-203

FERRERA, Maurizio, «Italy: wars, political extramism, and the constrains to welfare reform», in, OBIngER, Herbert, PETERSEn, Klaus, StARKe Peter, Warfare and Welfare. Military Conflict and Welfare State Development in Western Countries, Oxford Up, Oxford, 2018, pp. 99-126

FRANCISCI, Giulio, «L'assicurazione obbligatoria contro la disoccupazione in Italia. Dalla Grande Guerra alla carta del lavoro», in Studi Storici, 2, 2018, pp. 367-401.

GAL, John, «The Puzzling Warfare-Welfare Nexus», War \& Society, 1, 2007, pp. 99-102

INPS, Per una storia della previdenza sociale in Italia. Studi e documenti, Roma, 1962

JACKSON, Christopher R., «Infirmative action: the Law of the Severely Disabled in Germany», Central European History, 1993, 26, n. 4, pp. 417-55.

Klausen, Jytte, War and Welfare. Europe and the United States, 1945 to the present, Palgrave, London 1998

KoHLER, Peter A., et al. (eds), The Evolution of Social Insurance 1881-1981: Studies of Germany, France, Great Britain, Austria and Switzerland, London-New York, F. Pinter-St. Martin's Press, 1982 
Labanca, Nicola (ed.), Guerra e disabilità. Mutilati e invalidi italiani e disabilità, Unicopli, Paodva 2016

LIEBESKIND SAUTHIER, I., «Modern Unemployment: From the Creation of the Concept to the International Labour Office's First Standards» in KotT, SANDRINE, Droux (ed.), J., Globalizing Social Rights - The International Labour Organization and Beyond, New York, Palgrave Macmillan, 2013, pp. 67-84

LINKER, Beth, War's waste. Rehabilitation in World War I America, ChicagoLondra, University of Chicago Press, Chicago, 2011

Luzzati, Enrico, Portesi Roberto, La spesa pubblica, in Cassese, Sabino, L'amministrazione centrale, UTET, 1984, Torino.

MASINA, Filippo, «Il collocamento obbligatorio dei reduci di guerra. Il caso italiano nel contesto internazionale del secondo dopoguerra, 1945-1946», Italia Contemporanea, 2018, 288, pp. 39-71

MORTARA, Giorgio, La salute pubblica in Italia durante e dopo la guerra, Bari, Laterza, 1925

Moses, Julia, The first modern risk. Workplace accidents and the Origins of European Social states, Cambridge UP, Cambridge 2018

NITTI, Francesco Saverio, La legislazione sociale in Italia [1892], ora in Scritti sulla questione meridionale, vol. I, 1958, Bari.

Obinger, Herbert, Petersen, Klaus, «Mass Warfare and the Welfare StateCausal Mechanisms and Effects», British Journal of Political Science, 1, 2017, pp. 203-27

Obinger, Herbert, Petersen, Klaus, Starke, Peter, Warfare and Welfare. Military Conflict and Welfare State Development in Western Countries, Oxford Up, Oxford, 2018

Pavan Della Torre, Ugo, «Entre public et privé: l'assistance aux invalides de guerre et les origines d'un nouveau système de welfare en Italie (19151923). Notes et perspectives de recherches», in Revue d'histoire de la protection sociale, 8,2016 , pp. 45-64

Pietravalle, Michele, «Per un ministero della Sanità ed Assistenza pubblica in Italia», Nuova Antologia, gennaio-aprile 1919, pp. 104-117

PIRONTI, Pierluigi, «Grande guerra e Stato sociale in Italia. Assistenza a invalidi e superstiti e sviluppo della legislazione sulle pensioni di guerra», Italia contemporanea, 207, 2105, pp. 63-89

PRocacci, Giovanna, Warfare-welfare. Intervento dello Stato e diritti dei cittadini (1914-1918), Carocci, Roma, 2013

Quagliaroli, Fabiano, «Le pensioni per gli invalidi della Prima guerra mondiale», Contemporanea, 1, 2016, pp. 43-67

QuAgliaroli, Fabiano, Risarcire la nazione in armi. Il Ministero per l'Assistenza Militare e le Pensioni di guerra (1917-1923), Unicopli, Padova 2018

RAPINI, Andrea, «Attori, spazi e saperi della riforma sociale in Italia attorno alla Grande Guerra», Passato e Presente, 2016, 99, pp. 59-86 
War and the Welfare State: The Case of Italy, from WWI to Fascism

RAPINI, Andrea, «Il discorso politico di L. R.: lavoro, democrazia, riforma sociale», in Momenti del welfare in Italia. Storiografia e percorsi di ricerca, a cura di P. MATTERA, Roma 2012, pp. 17-53

RASMUSSEN, Anna, «Protéger la société de la guerre: de l'assistance aux 'droits sur la nation'», in Guerre et protection sociale, Revue d'histoire de la protection sociale, 9,2016, p. 8-22

Rigola, Rinaldo, «Le classi operaie e le assicurazioni sociali», Rassegna Sociale. Rivista mensile della Cassa Nazionale d'Assicurazione per gli infortuni degli operai sul lavoro, 5, 1918, n. 1

ROMIEN, Pierre, «À l'origine de la réinsertion professionnelle des personnes handicapées: la prise en charge des invalides de guerre», Revue Française des Affaires sociales, 2005, 2, p. 229-247

Salvante, Martina, «Thanks to the Great War the Blind Gets the Recognition of his Ability to Act: The Rehabilitation of Blinded Servicemen in Florence», First World War Studies, 6, 2015, n. 1, pp. 21-35

SCHEIDEL, Walter, The Great Leveler. Violence and the History of Inequality from the Stone Age to the Twenty-First Century, Princeton UP, Princeton, 2017

Scheuerman, William E., Between the Norm and the Exception: The Frankfurt School and the Rule of Law, MIT Press, Cambridge-Mass., 1994

Scheve, Kenneth, Stasavage, David, Taxing the Rich A History of Fiscal Fairness in the United States and Europe, Princeton UP, Princeton, 2017

SERPIERI, Arrigo, La guerra e le classi rurali italiane, Bari: Laterza \& Figli; New Haven: Yale University Press, 1930

TACCHI, Francesco, «Prisma cattolico e "legislazione sociale-operaia". Il gruppo della "Rivista internazionale di scienze sociali" al tempo di Giuseppe Toniolo», Modernism, 2015, 1, pp. 272-301

ThÉBAuD, Françoise, «La Grande Guerra: età della donna o trionfo della differenza sessuale?», in G. Duby e M. PERrot (a cura di), Storia delle donne. Il Novecento (1996), Bari, Laterza, 2003.

VASSALLI, Filippo, «Prolusione al corso di Istituzioni di diritto civile», Genova 22 novembre 1918, pubblicata in Rivista di diritto commerciale, 1919 con il titolo "Della legislazione di guerra e dei nuovi confini del diritto privato (ora in Vassalli, Filippo, Studi giuridici, vol. II, Giuffè, Milano, 1967, pp. 337 e sgg.)

Wall VoIr, Richard, Winter, Jay (eds), The Upheaval of War: Family, Work and Welfare in Europe, 1914-1918, Cambridge, Cambridge University Press, 1988

Winter, Jay, Robert, Jean-Louis (eds), Capital Cities at War: Paris, London, Berlin 1914-1919, Cambridge, Cambridge University Press, 1997-2007, 2 vol. 


\section{Datos sobre la autora}

Ilaria Pavan. Recibió su Doctorado en Historia por la Scuola Normale Superiore de Pisa, donde es Profesora Asociada de Historia Contemporánea. Sus principales campos de investigación son la historia de los judíos en Italia; la Historia del Fascismo, y la Historia del estado de bienestar italiano. Ha editado, con Paolo Mattera, «El estado de bienestar italiano desde una perspectiva supranacional. Historia y debates» Journal of Modern Italian Studies, 22: 2, 2017. Es editora gerente de Contemporanea. Rivista di storia dell'800 e del '900. 